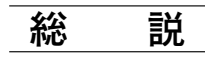

\title{
めまいと酸塩基平衡障害
}

\author{
中村 節子（旧姓森中）
}

\section{Vertigo and acid-base imbalance}

\author{
Setsuko Morinaka-Nakamura \\ Department of Otorhinolaryngology, Kobe Japanpost Hospital
}

There have been several reports about the relation between acid-base imbalance or arterial blood gas abnormalities and the occurrence of vertigo, including Meniere' disease. In animal experiments, respiratory acidosis induced by $\mathrm{CO}_{2}$ inhalation or metabolic acidosis induced by injection of $\mathrm{NH}_{4} \mathrm{Cl}$ has been shown to cause attacks of vertigo in rabbits with hemilabyrinthectomy. In clinical studies, approximately half of the patients with dizziness have arterial blood gas abnormalities when their dizziness occurs. An increase of $\mathrm{HCO}_{3-}$ is found in many patients with dizziness, and the frequency of attacks is higher in patients who have arterial blood gas abnormalities during the remission period. These patients are thought to have unilateral vestibular dysfunction, and it is suggested that arterial blood gas abnormalities cause temporary vestibular dehabituation that increases the frequency of dizziness. It has also been reported from a study that the middle ear pressure difference between both ears, which is larger during periods of dizziness or recurrent dizziness than at the time of remission, might be related to blood gas abnormalities in Meniere's disease. In the same study, a difference of more than 50 decapascals was significantly more common in the patient group with blood gas abnormalities. In addition, metabolic acidosis has been reported in patients with Meniere's disease, and the base excess and bicarbonate levels were also found to be beyond the normal range in Meniere's disease. Arterial blood gas abnormalities might develop for various reasons, including underlying diseases and middle ear pressure differences. The endolymph in the endolymphatic sac is acidic ( $\mathrm{pH} \mathrm{6.6-7).} \mathrm{It}$ has been reported that carbonic anhydrase, vacuolar $\mathrm{H}^{+}$-ATPase, pendrin and aquaporin may participate in the acidification process or homeostasis. The role of acid-base disturbance or arterial blood gas abnormalities in dizziness, and the relation in acid-base balance between inner ear and arterial blood gas need to be investigated further.

Key words: acidosis, arterial blood gas abnormalities, vertigo

緒言

生体が健康であるためには酸塩基平衡が適正で 血液 $\mathrm{pH}$ が正常に保たれる必要がある。体内の酸 
塩基過不足で $\mathrm{pH}$ は変動し酸塩基平衡異常が生じ る。酸塩基平衡異常は呼吸性アシドーシス（炭酸 ガスの蓄積), 代謝性アシドーシス（固定酸の蓄 積), 呼吸性アルカローシス (炭酸ガスの不足), 代謝性アルカローシス（固定酸の不足）に大別さ れる。生体には緩衝, 代償などの調節機構があり, 呼吸性異常は代謝性変化を, また代謝性異常は呼 吸性変化を引き起こして $\mathrm{pH}$ 変動を調節してい $る^{1)}$ 。肺は呼吸, 腎臓は尿中への水素イオン排出 や重炭酸イオン産生調節を介し酸塩基平衡に関与 している ${ }^{2)}$ 。血液ガスは血液中の気体の意である が, 実際には血液ガス測定は酸塩基平衡検査の意 であり両者間に区別がない ${ }^{3)}$ 。また肺疾患の多く は高 $\mathrm{CO}_{2}$ 血症と低 $\mathrm{O}_{2}$ 血症を同時に招くなど, $\mathrm{CO}_{2}$ や $\mathrm{O}_{2}$ 単独の異常はまれで, 主な病態が高 $\mathrm{CO}_{2}$ 血 症または低 $\mathrm{O}_{2}$ 血症であっても他の変化を合併す ることが多い゙)。

内耳に打ける酸塩基平衡の報告は多いが, 血液 ガス・酸塩基平衡異常とめまいに関する報告は少 ない。本稿では酸塩基平衡とめまいに関連すると 思われる過去の報告の概観を述べ，私見を加えた い。

\section{酸塩基平衡異常とめまいに関する動物実験}

1）血液ガス・酸塩基平衡異常とめまい

血液ガス・酸塩基平衡障害とめまいの動物実験 に関する報告は少ない。近藤 ${ }^{5)}$ は1929年に片側迷 路破壊性眼振が出現中のウサギに対し, 炭酸ガス 吸入による眼振頻度や振幅の変化を観察し, 炭酸 ガス吸入が片側迷路破壊性眼振に影響するのを示 した。しかしながら近藤(5) は片側迷路破壊性眼振 が代償され消失した後に炭酸ガスの吸入実験は行 っていない。

Morinaka ${ }^{6}$ は1994年にウサギのアシドーシスと めまいに関する報告を行った。まず片側迷路破壊 性眼振出現中と正常コントロールの血液ガスを測 定し $\mathrm{pH}$ を比較したが統計的有意差はなかった。 破壊は全例右側に行った。

次に片側迷路破壊性眼振消失後に代謝性アシド ーシスを引き起こす目的で塩化アンモニウム $\left(\mathrm{NH}_{4} \mathrm{Cl}\right)$ を静注すると全例に眼振が再出現し体 平衡は悪化した。眼振方向は健側向き 2 羽, 破壊 側向き 3 羽, 健側向きより破壊側向きに変化した のが 4 羽であった（表 1 , 図 1 a )。この眼振消 失後の再投与でも眼振は再出現した。血液ガス分
析例は $\mathrm{pH}$ 低下を示した。正常ウサギへの $\mathrm{NH}_{4} \mathrm{Cl}$ 静注や片側迷路破壊性眼振消失後の生理食塩水静 注では眼振出現や体平衡悪化はなかった（表 1 , 図 1 b)。

次に片側迷路破壊性眼振消失後のウサギに呼吸 性アシドーシスを起こす目的で炭酸ガスを吸入さ せると眼振が再出現し体平衡は悪化した。眼振方 向は破壊側向きであった（表 1 , 図 $1 \mathrm{c}$ )。再度 の実験でも同様であった。炭酸ガス吸入で血液 $\mathrm{pH}$ は低下, 動脈血 $\mathrm{CO}_{2}$ 分圧 $\left(\mathrm{PaCO}_{2}\right)$ は上昇し た。正常コントロールでは炭酸ガス吸入による眼 振誘発や体平衡の変化はなかった（表 1 )。

以上より呼吸性や代謝性アシドーシスは代償状 態の片側迷路破壊後ウサギに, めまい再発を引き 起こすことが示された。これは呼吸性や代謝性ア シドーシスが前庭代償状態を破綻させてめまい再 発作を引き起こすことを示唆している。なお正常 コントロールや片側迷路破壊性眼振消失後のウサ ギ 3 羽に代謝性アルカローシスを引き起こす目的 で 7 \%炭酸水素ナトリウム (メイロン ${ }^{\circledR}$ ) $20 \mathrm{ml}$ を静注して投与したが眼振は誘発されず体平衡変 化もなかった。このうち 2 羽に血液ガス測定を行 い, $\mathrm{pH}$ 上昇を確認した $(7.409 \rightarrow 7.654,7,343 \rightarrow$ 7.486) (デー夕未発表)。

\section{2) 内耳に打ける酸塩基平衡}

以上, 血液ガス・酸塩基平衡障害とめまいに関 する動物実験について述べたが，内耳局所におけ る酸塩基平衡も重要である。内リンパ囊の内リン

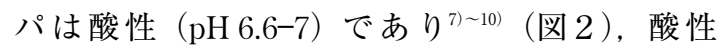
であることは内リンパ囊の機能に重要であると考 えられている ${ }^{8)}$ が，内リンパ震における酸塩基平 衡の調節機構はいまだ不明であるとされてい る ${ }^{10)}$ 。

炭酸脱水酵素 carbonic anhydrase（CA） は $\mathrm{CO}_{2}$ $+\mathrm{H}_{2} \mathrm{O} \rightarrow \mathrm{HCO}_{3}{ }^{-}+\mathrm{H}^{+}$の反応を迅速に変換する酵 素である。 $\mathrm{CO}_{2}$ と $\mathrm{HCO}_{3}{ }^{-}$の相互変換により, 血 液や組織の $\mathrm{pH}$ の変動を抑制して酸塩基平衡を維 持し, $\mathrm{CO}_{2}$ を排出する補助を行う ${ }^{11)}$ 。CA には $\alpha$ から $\varepsilon$ のファミリーがあり, 哺乳類に存在する $a-$ CA には細胞質性 (CA-I, CA-II, CA-III, CA-VII, $\mathrm{CA}-\mathrm{XIII})$, ミトコンドリア性 (CA-VA, CA$\mathrm{VB})$, 分泌型 (CA-VI) と膜結合型 (CA-IV, CAIX, CA-XII, CA-XIV, CA-XV) のサブグループ があり，括弧内に記したアイソザイムが属してい 
表 1 眼振誘発における実験的アシドーシスの効果

\begin{tabular}{|c|c|c|c|}
\hline 実験 & 実験例数 & 眼振出現例数 & 眼振の方向例数 \\
\hline \multicolumn{4}{|c|}{ 片側（右）迷路破壊性眼振の消失後 } \\
\hline $\mathrm{NH}_{4} \mathrm{Cl}$ 静注 & 9 & $9^{\#}$ & 左 2 , 右 3 , 左から右へ 4 \\
\hline 生理食塩水静注 & 5 & $0^{*}$ & - \\
\hline $\mathrm{CO}_{2}$ 吸入 & $6^{+}$ & $5^{\# \#}$ & 右 5 \\
\hline $\mathrm{CO}_{2}$ 吸入なし & 2 & $0^{*}$ & - \\
\hline \multicolumn{4}{|l|}{ 正常 } \\
\hline $\mathrm{NH}_{4} \mathrm{Cl}$ 静注 & 5 & $0^{*}$ & - \\
\hline 生理食塩水静注 & 3 & $0^{*}$ & - \\
\hline $\mathrm{CO}_{2}$ 吸入 & 3 & $0^{*}$ & - \\
\hline $\mathrm{CO}_{2}$ 吸入なし & 2 & $0^{*}$ & - \\
\hline
\end{tabular}

\# : 眼振潜時 $0 \sim 10 \mathrm{sec}$ (平均 $3.1 \mathrm{sec}$ ), 眼振持続時間 $0.5 \sim 36 \mathrm{~min}$ (平均 $9.6 \mathrm{~min}$ )

\# \# : 眼振潜時 $0 \sim 40 \mathrm{sec}$ (平均 $15 \mathrm{sec}$ ), 眼振持続時間 $1.8 \sim 7.2 \mathrm{~min}$ (平均 $4.2 \mathrm{~min}$ )

*: 静注や吸入後 1 時間の観察で眼振発現せず。

+ : $\mathrm{CO}_{2}$ 吸入中に 1 羽のウサギは死亡。

(文献 6 より許可を得て引用)

る ${ }^{12)}$ 。CA II は $\mathrm{Na}^{+} / \mathrm{H}^{+}$交換体の制御に関与して いる ${ }^{13)}$ 。Yamashita $ら^{14)}$ や Tsujikawa $ら^{7)}$ は細胞質 性 CA が内リンパ囊に存在することや CA 阻害薬 （アセタゾラミド）の実験により酸性化に関与し うることを報告した。

尿細管，膀胱などの表層の細胞膜にはプロトン ポンプである液胞型 $\mathrm{H}^{+}$-ATPase（vacuolar (v) $\mathrm{H}^{+}$-ATPase）が存在し，陽イオンである $\mathrm{H}^{+}$の輸 送や $\mathrm{H}^{+}$の電気化学的ポテンシャル差により酸性 化を行う細胞膜の機能を担っている。また細胞に は内部が酸性で exocytosis や endocytosis に関わ る酸性オルガネラが存在, この内膜でも $\mathrm{vH}^{+}-\mathrm{AT}$ Pase がその機能をも担っている ${ }^{15)}$ 。Pendrin は陰 イオン輸送体であり, $\mathrm{I}^{-}, \mathrm{Cl}^{-}, \mathrm{HCO}_{3}^{-}, \mathrm{OH}^{-}$, $\mathrm{SCN}^{-}$, 蟻酸塩の運搬を行う SLC26A 4 (PDS) 遺伝子にコードされているタンパクである。甲状 腺ホルモン合成に不可欠なヨード取り込みを行う PDS 遺伝子が近年クローニングされ, 解析が進 んでいる ${ }^{16)}$ 。Stanković ら ${ }^{9)}$ P Everett ら ${ }^{17)}$ は $\mathrm{vH}^{+}$ATPase や Pendrin の mRNA やタンパクも内リン パ裹に発現していることを証明し, $\mathrm{vH}^{+}$-ATPase や Pendrin は内耳での $\mathrm{pH}$ 調節や内リンパのイオ ン調整に重要な役割を果たしていると考えられて いる。

2004年にDou ${ }^{10)}$ は酸塩基調節を担う $\mathrm{vH}^{+}$-

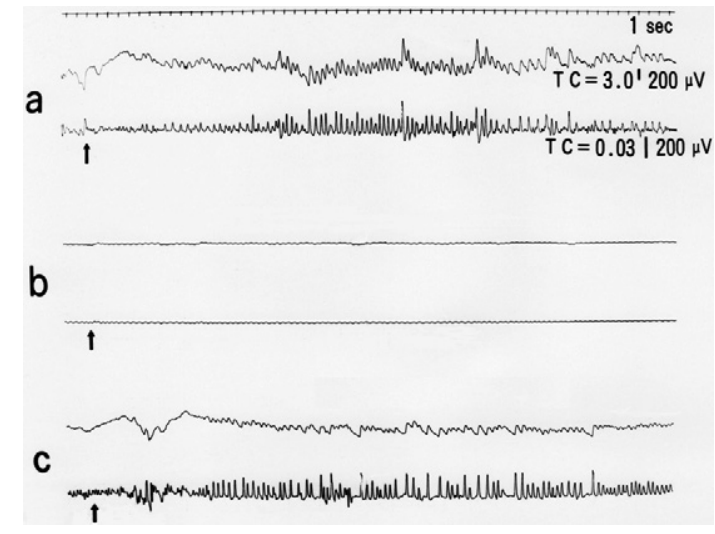

図 1 眼振の典型例

片側（右）迷路破壊後に破壊性眼振が完全に 消失したウサギを使用し， $\mathrm{a}: \mathrm{NH}_{4} \mathrm{Cl}$ を静注 すると破壊側向き眼振が誘発され， b : 生理 食塩水の静注では眼振は誘発されず, $\mathrm{c}$ : $\mathrm{CO}_{2}$ を吸入させると破壊側向き眼振が誘発さ れた。やは静注または吸入の終了時点を示 す。

(文献 6 より許可を得て転載)

ATPase (proton pump), 細胞質性 CA II, pendrin をネズミの内リンパ囊上皮において免疫組織学的 に染色し，また染色パターンを二重染色により比 較した。これにより pendrin と $\mathrm{vH}^{+}$-ATPase は共 に特殊タイプの内リンパ襄の上皮膜尖端に存在 
Equilibrium Res Vol. 72(3)

表2 めまい疾患における血液ガス異常一覧

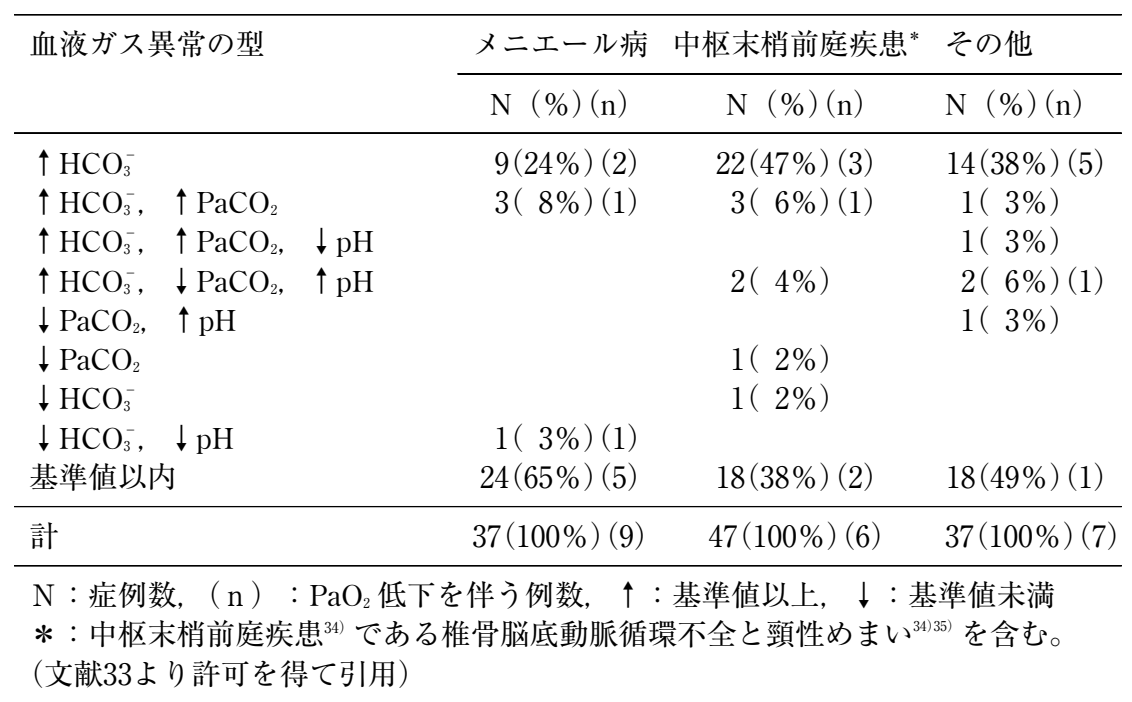

し, これら陽性細胞では CA II が発現しているこ とを示した。この特殊タイプの内リンパ囊の細胞 が内リンパ囊の酸塩基平衡に重要な役割を持ち, pendrin, $\mathrm{vH}^{+}$-ATPase, CA II はこのプロセスに 関与することを示唆した。

臓器により水の透過性は異なる。この透過性の 違いは水のみを選択的に通過させるチャンネルタ ンパク（水チャンネル）の存在の有無によること が近年明らかとなり, 水チャンネル遺伝子ファミ リーの統一名称としてアクアポリン (Aqp) が提 唱された。Aqpは 0 から13まで登録されており, Aqp 6 はイオンチャンネルとしても機能すること が明らかになってきている ${ }^{18)}$ 。Fukushima ${ }^{19)} ら は$ Aqp 1，3-6の mRNA が内リンパ囊に発現して いるのを報告し, Taguchiらは ${ }^{20)} 2008$ 年にRTPCR, 免疫蛍光顕微鏡検査, 免疫電子顕微鏡によ り Aqp 6 の mRNA とタンパクが血管条, 内リン パ裹, 前庭の細胞内小胞の膜に存在していること を示した。これより Aqp 6 は内リンパ液の酸塩基 平衡や水代謝のホメオスタシスに関与する可能性 が考えられると報告した。

先に述べた pendrin の変異は内耳リンパの酸性 化をおこし，甲状腺腫と共に前庭機能低下による 反復性めまいや難聴の原因となり, Pendred 症候 群をおこすとされる ${ }^{2122)}$ 。内耳での制御機構など 基礎的研究は他にも多数あり ${ }^{23)} 27$, 今後, 血液ガ

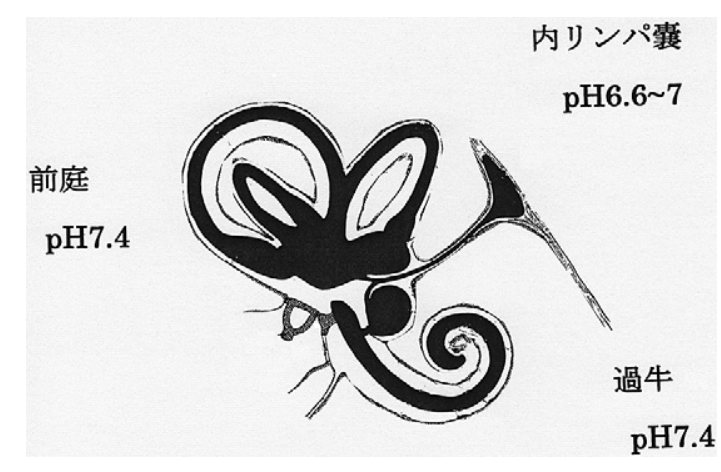

图 2 内リンパの $\mathrm{pH}$

内リンパ囊の内リンパは酸性であり, 前庭や 過牛の内リンパの $\mathrm{pH}$ と異なることが報告さ れている7) 10)。

スと内リンパ䡬・内耳の酸塩基平衡との関係につ いても解明がすすむものと期待される。

\section{血液ガス・酸塩基平衡異常とめまいに関する臨 床的報告}

血液ガス・酸塩基平衡障害とめまいの臨床的報 告も少ない。高橋ら ${ }^{2829)}$ は1982年に 3 例のメニエ 一ル病について $\mathrm{pH}$, 血漿 $\mathrm{HCO}_{3}$ 濃度 $\left(\mathrm{HCO}_{3}{ }^{-}\right)$, 塩基過剩 (base excess : $\mathrm{BE}$ ), $\mathrm{PaCO}_{2}$ を測定し て報告をした。これら 3 例は全例ともめまい発作 時は代謝性アシドーシスを示し 2 例は呼吸性アシ ドーシスを合併していた。めまい発作後に 1 例は 
表3 めまい緩解期の後に再発をきたした頻度

\begin{tabular}{|c|c|c|c|c|}
\hline \multicolumn{3}{|l|}{ めまい期 } & \multicolumn{2}{|l|}{ 緩解期 } \\
\hline & & & 血液ガス異常群 & 血液ガス正常群 \\
\hline 血液ガス異常の型 & & $\mathrm{N}$ & $\mathrm{N}(\mathrm{n})$ & $\mathrm{N}(\mathrm{n})$ \\
\hline$\uparrow \mathrm{HCO}_{3}^{-}$ & & 9 & $4(2)$ & $5(0)$ \\
\hline$\uparrow \mathrm{HCO}_{3}^{-}, \quad \uparrow \mathrm{PaCO}_{2}$ & & 2 & $2(2)$ & \\
\hline$\uparrow \mathrm{HCO}_{3}^{-}, \quad \uparrow \mathrm{PaCO}_{2}$ & $\downarrow \mathrm{pH}$ & & & \\
\hline$\uparrow \mathrm{HCO}_{3}^{-}, \quad \downarrow \mathrm{PaCO}_{2}$ & $\uparrow \mathrm{pH}$ & 1 & $1^{a}(1)$ & \\
\hline$\downarrow \mathrm{PaCO}_{2}$ & & 1 & $1^{b}(0)$ & \\
\hline$\downarrow \mathrm{HCO}_{3}^{-}$ & & & & \\
\hline$\downarrow \mathrm{HCO}_{3}^{-}, \quad \downarrow \mathrm{pH}$ & & 1 & $1^{\mathrm{a}}(1)$ & \\
\hline 基準值以内 & & 8 & $3^{\mathrm{c}}(0)$ & $5(0)$ \\
\hline 計 & & 22 & $12(6)$ & $10(0)$ \\
\hline
\end{tabular}

$\mathrm{N}$ ：症例数, ( n ) : 緩解期の後にめまいを再発した症例数, ${ }^{\mathrm{a}, \mathrm{b}, \mathrm{c}}$ ：めまい期 の血液ガス異常とは異なる血液ガス異常を緩解期に呈した症例の血液ガス異 常の型 $\left({ }^{\mathrm{a}}: \uparrow \mathrm{HCO}_{3}{ }^{-},{ }^{\mathrm{b}}: \downarrow \mathrm{PaCO}_{2}, \uparrow \mathrm{pH},{ }^{\mathrm{c}}: \uparrow \mathrm{HCO}_{3}{ }^{-} 2\right.$ 例, $\downarrow \mathrm{PaCO}_{2} 1$ 例), $\uparrow$ : 基準值以上, $\downarrow$ : 基準值未満 （文献33より許可を得て引用）

$\mathrm{pH}$ の改善, 2 例は $\mathrm{BE}$ と $\mathrm{HCO}_{3}{ }^{-}$の改善が認めら れた。

牧本 ${ }^{30)}$ は1977年に $\mathrm{pH}, \mathrm{HCO}_{3}{ }^{-}, \mathrm{BE}, \mathrm{PaCO}_{2}$ 測 定でメニエール病患者に代謝性アシドーシス傾向 例が多く 10 症例中 6 症例はこの傾向で, 3 例は完 全な代謝性アシドーシスを呈していたと報告して いる。

Celestino ら ${ }^{311}$ は1973年に1. 高血漿浸透 圧，2．低眼圧，3．アシドーシス化やグリセロ 一ル投与で症状は悪化, 4 . 水負荷で改善という 特徵がある代謝性アシドーシスの 1 例のメニエー ル病について報告した。高張性脱水症に関連した 症例で, メニエール病においては水電解質を検査 して症例ごとに適する治療法を取り入れる必要が あるとしている。

またCelestino ら ${ }^{32)}$ は1976年に $\mathrm{pH}, \quad \mathrm{PaCO}_{2}$, 基 準重炭酸塩 (standard bicarbonate: SB), BEを 57例のメニエール病で測定し, 39例の代謝性アル カローシス，4例の代謝性アシドーシスがあった と報告した。 $1 \sim 3$ 年の経過観察で代謝性変化と メニエール病の症状経過は平行したが, 炭酸水素 ナトリウムの内服誘発テスト 2 回のうち 1 回しか めまいは誘発されなかったとしている。アルカロ
ーシスを伴う症例に酸塩基平衡を是正する治療を 行うと急性過牛前庭症状は軽快し, この治療中断 により症状再発をみたと報告している。メニエー ル病における代謝性アルカローシスの生理学的, 病理学的意義はいまだ不明であり, 代謝性アルカ ローシスは内リンパ水腫の素因として考慮しうる に留まると述べている。

Morinaka ら33) は1998年にめまい患者121例に動 脈血ガス分析を行い報告した。めまい期には 50. $4 \%$ にH, $\mathrm{HCO}_{3}{ }^{-}$や $\mathrm{PaCO}_{2}$ 異常があった。 その $93.4 \%$ は $\mathrm{HCO}_{3}{ }^{-}$増加（代謝性アルカローシ ス）で最も多く, $\mathrm{HCO}_{3}{ }^{-}$単独増加は45例だった。 8 例は $\mathrm{PaCO}_{2}$ 上昇を伴い, うち 1 例は $\mathrm{pH}$ 低下 を伴った。 $\mathrm{PaCO}_{2}$ 低下は 6 例, $\mathrm{pH}$ 上昇は 5 例, 低下は 2 例だった（表 2 )。 $\mathrm{HCO}_{3}{ }^{-}$上昇の原因疾 患等は少なく, $\mathrm{HCO}_{3}^{-}$増加（代謝性アルカローシ ス）の原因は呼吸性アシドーシスの代償が考えら れた。

中枢前庭の障害や異常を示す中枢末梢前庭疾 患 ${ }^{34)}$ である椎骨脳底動脈循環不全および頸性めま ( ${ }^{3435)}$ やメニエール病も $\mathrm{HCO}_{3}{ }^{-}$上昇が最も多く (表 2 ), 血液ガス異常はメニエール病より椎骨脳 底動脈循環不全（および頸性めまい）で有意に多 
Equilibrium Res Vol. 72(3)

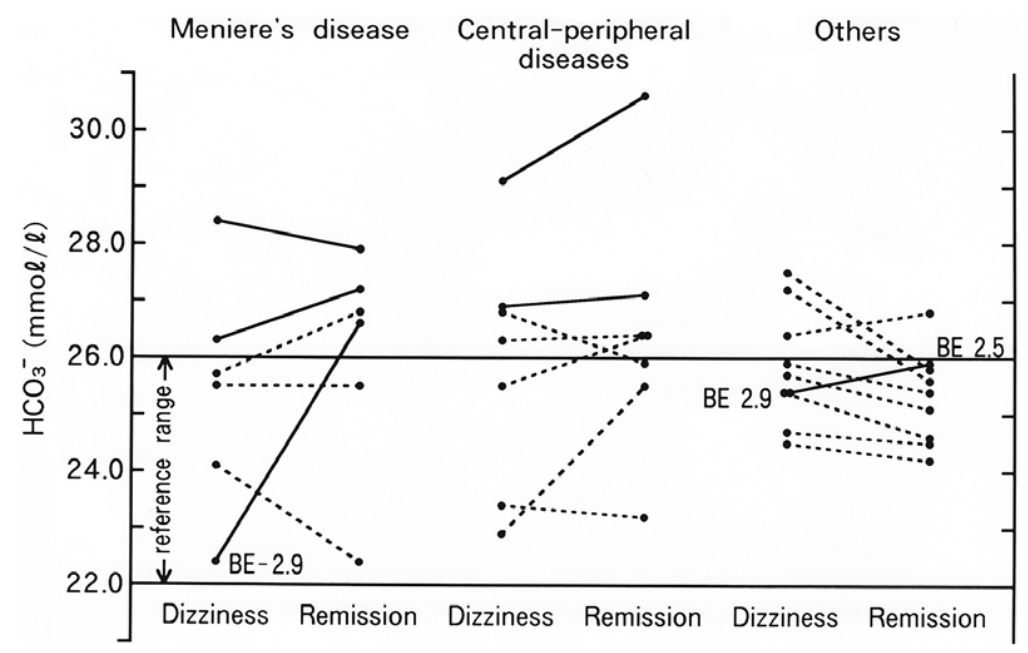

図3 めまい期とめまい緩解期における 22 例の血漿 $\mathrm{HCO}_{3}$ 濃度 $\left(\mathrm{HCO}_{3}^{-}\right)$レベル

実線, 点線はそれぞれ緩解期後にめまいが再発した例, 再発しなかった例を示す。塩基過剩 (base excess：BE）は異常值を示した例のみ表示してある。

(文献33より許可を得て転載)

表4 めまい疾患において中耳圧を検討した症例の血液ガス異常一覧

\begin{tabular}{|c|c|c|c|}
\hline \multirow{2}{*}{ 血液ガス異常の型 } & \multicolumn{3}{|c|}{ 症例数 } \\
\hline & メニエール病 & 頸性めまい & 椎骨脳底動脈循環不全 \\
\hline$\uparrow \mathrm{HCO}_{3}^{-}$ & 7 & 13 & 4 \\
\hline$\uparrow \mathrm{HCO}_{3}^{-}, \quad \uparrow \mathrm{PaCO}_{2}$ & 2 & 1 & 1 \\
\hline$\uparrow \mathrm{HCO}_{3}{ }^{-}, \quad \downarrow \mathrm{PaCO}_{2}, \quad \uparrow \mathrm{pH}$ & & & 1 \\
\hline$\downarrow \mathrm{PaCO}_{2}$ & & 1 & \\
\hline$\downarrow \mathrm{HCO}_{3}^{-}$ & & & 1 \\
\hline$\uparrow \mathrm{HCO}_{3}^{-}, \quad \downarrow \mathrm{PaO}_{2}$ & 2 & 2 & 1 \\
\hline$\uparrow \mathrm{HCO}_{3}{ }^{-}, \quad \uparrow \mathrm{PaCO}_{2}, \quad \downarrow \mathrm{PaO}_{2}$ & 1 & & 1 \\
\hline$\downarrow \mathrm{HCO}_{3}^{-}, \quad \downarrow \mathrm{pH}, \quad \downarrow \mathrm{PaO}_{2}$ & 1 & & \\
\hline$\downarrow \mathrm{PaO}_{2}$ & 5 & 2 & \\
\hline 基準值以内 & 19 & 8 & 6 \\
\hline 計 & 37 & 27 & 15 \\
\hline
\end{tabular}

$\uparrow$ : 基準值以上, $\downarrow$ : 基準值未満

（文献36より許可を得て引用）

かった $\left(\mathrm{p}<0.02, \quad \chi^{2}\right.$ テスト $)$ 。中枢性呼吸機能 障害の可能性や中枢前庭障害で前庭代償破綻を起 こしやすい可能性が示唆された。

動脈血 $\mathrm{O}_{2}$ 分圧 $\left(\mathrm{PaO}_{2}\right)$ 低下は22例で $\mathrm{PaO}_{2}$ 単 独低下は 8 例だった（表 2$)$ 。メニエール病と椎 骨脳底動脈循環不全（および頸性めまい）間に $\mathrm{PaO}_{2}$ 低下数の有意差はなかった。 $\mathrm{PaO}_{2}$ 低下原因
の疾患は少なく, $\mathrm{PaO}_{2}$ 低下原因の可能性として 代謝性アルカローシス, $\mathrm{PaCO}_{2}$ 上昇が示唆され た。

めまい緩解期血液ガス分析は 22 例に行った。12 例に軽度血液ガス異常が残存, 10例は基準值内だ つた。緩解期に異常值を示した12例のうち 6 例は 1 力月以内にめまいが再発したが, 基準值以内の 
表 5 中耳圧の左右差と血液ガス異常の比較

\begin{tabular}{lcc}
\hline \multicolumn{1}{c}{ 診断 } & $\begin{array}{c}\text { 中耳压の左右差 } \\
\text { 平均值 } \pm \mathrm{SD}(\mathrm{daPa})\end{array}$ & 症例数 \\
\hline 正常コントロール & $1.6 \pm 5.7$ & 33 \\
メニール病 & $27.6 \pm 37.6$ & 37 \\
血液ガス異常群*** & $38.0 \pm 46.3$ & 18 \\
血液ガス正常群** & $13.7 \pm 18.4$ & 19 \\
頸性めまい & $12.6 \pm 32.7$ & 27 \\
血液ガス異常群* & $14.6 \pm 38.3$ & 19 \\
血液ガス正常群 & $6.7 \pm 13.0$ & 8 \\
椎骨脳底動脈循環不全 & $48.9 \pm 55.1$ & 15 \\
血液ガス異常群**** & $63.2 \pm 53.3$ & 9 \\
血液ガス正常群 & $27.3 \pm 55.0$ & 6 \\
\hline
\end{tabular}

正常コントロールとの比較（Wilcoxon-Mann-Whitney test） ${ }^{* * *} \mathrm{p}<0.001, \quad{ }^{* *} \mathrm{P}<0.005, \quad{ }^{*} \mathrm{P}<0.01$

（文献36より許可を得て引用）

表 6 中耳圧の左右差 $50 \mathrm{daPa}$ 以上の症例数と血液ガス異常の関連

\begin{tabular}{lccc}
\hline & \multicolumn{3}{c}{ 中耳压の左右差 } \\
\cline { 2 - 4 } & $\geqq 50 \mathrm{daPa}$ & $<50 \mathrm{daPa}$ & 計 \\
\hline 正常コントロール & 0 & 33 & 33 \\
メニエル病 & 7 & 30 & 37 \\
血液ガス異常群* & 6 & 12 & 18 \\
血液ガス正常群 & 1 & 18 & 19 \\
頸性めまい & 1 & 26 & 27 \\
血液ガス異常群 & 1 & 18 & 19 \\
血液ガス正常群 & 0 & 8 & 8 \\
椎骨脳底動脈循環不全 & 7 & 8 & 15 \\
血液ガス異常群 & 6 & 3 & 9 \\
血液ガス正常群 & 1 & 5 & 6 \\
\hline
\end{tabular}

$* \mathrm{p}<0.05 （ \chi^{2}$ テスト $)$ 血液ガス異常群と血液ガス正常群の例数の比較 （文献36より許可を得て引用）

10例には再発例はなかった $\left(\mathrm{p}<0.01, \quad \chi^{2}\right.$ テス ト）（表 3$) 。 \mathrm{HCO}_{3}{ }^{-}$レベルは再発しなかった例 より再発した例が有意に高かった $(\mathrm{p}<0.01$, Wilcoxon-Mann-Whitney test）（図 3 ）。

以上よりめまい患者の約半数に血液ガス異常が あり, メニエール病と椎骨脳底動脈循環不全（お よび頸性めまい）では血液ガス異常により前庭代 償の破綻をきたしてめまいの頻度が多くなること が示唆された。

また Morinaka ら ${ }^{36)}$ は2004年にめまい患者112
名の左右チンパノグラムを重ねて最大コンプライ アンスのピークを結ぶ線（チンパノピークライ ン）を引き, 中耳圧左右差を検討した。そのうち 79名（メニエール病37例, 頸性めまい27例, 椎骨 脳底動脈循環不全15例）については血液ガス測定 を行い（表 4), 血液ガス・酸塩基平衡異常と中 耳圧差との関連について検討した。血液ガス異常 群, 血液ガス正常群に分けて検討するとメニエー ル病のめまい期は両群とも中耳圧左右差は正常コ ントロールの中耳圧差よりも有意に大きかった。 
頸性めまいや椎骨脳底動脈循環不全は血液ガス異 常群のみ中耳圧差は正常コントロールょりも有意 に大きかった（表 5 )。またメニエール病で中耳 圧差を $50 \mathrm{daPa}$ 以上と $50 \mathrm{daPa}$ 未満に分けて検討 すると血液ガス異常群は血液ガス正常群より中耳 圧左右差 $50 \mathrm{daPa}$ 以上の症例が有意に多かった (表6)。

ちなみに中耳圧はめまい期のメニエール病, 頸 性めまい, 椎骨脳底動脈循環不全に左右のうち高 い側と低い側の間に有意差があり, 中耳圧左右差 は正常者より有意に大きかった。メニエール病で は中耳圧の低い側は正常者より有意に低く，めま い期やめまい再発期の中耳圧左右差はめまい緩解 期より有意に大きかった。頸性めまいは病期によ る差がなく, 椎骨脳底動脈循環不全はめまい期と 緩解期に差があった。またメニエール病では正常 者より最大コンプライアンスの低い側は有意に低 く, 最大コンプライアンス左右差は有意に大きか った。

中耳压左右差はメニエール病のめまいや再発に 大きく関連し, 頸性めまいや椎骨脳底動脈循環不 全も関連することが示唆された ${ }^{36)}$ 。 Tumarkin ${ }^{37)}$ は メニエール病には耳管機能不全があると報告し,

Hall \& Brackman ${ }^{38)}$ はメニエール病には中耳に除 圧があるとし, Merica ${ }^{39)}$ は 1 側または左右差の ある耳管狭窄があると報告しているが, Cinnamond $^{40)}$ は異常中耳圧側と患側が一致しない例が あるとし, Maier ら ${ }^{41}$ は常に耳管機能に異常があ るわけではないと反対意見を述べた。しかしなが ら Sakikawa ら ${ }^{42)}$ は内リンパ水腫動物では正常動 物より低い压で眼振が誘発されると報告し, Ingelstedt ${ }^{43)}$ は健常者でさえも左右差のある圧 を中耳に負荷するとめまいが引き起こされると報 告した。最近では Park ら ${ }^{44)}$ は反復してチンパノ メトリーを測定できる携帯用装置を用いて中耳圧 を長時間反復して測定し,メニエール病では突発 性難聴や正常者に比べて有意に低い中耳圧（平 均-43 daPa) を示したと報告した。病期による差, 患側と健側との差, 反復測定の間隔による差等の 報告が待たれる。

めまい期の血液ガス異常は中耳圧左右差に関連 することが示唆され (表 5 ), 特にメニエール病 では血液ガス異常は中耳圧の $50 \mathrm{daPa}$ 以上の左右 差と関連していた（表6)。これより異常中耳圧
は必ずしもメニエール病等の患側に作用するので はなく, 中耳压左右差がメニエール病, 頸性めま い, 椎骨脳底動脈循環不全における前庭系に影響 を及ぼす要因の 1 つになるのではないかと示唆さ れた。また，中耳圧と血液ガスに関して Buckingham ${ }^{45)}$ は $\mathrm{PaCO}_{2}, \mathrm{PaO}_{2}$ の変化は中耳圧変化を引

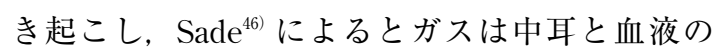
間に双方向への移動を起こすとのべている。呼吸 性アシドーシスを引き起こす疾患（頭部外傷, 肺 気腫, 気管支喘息, 脊柱変形, 肥満, 重症筋無力 症等）及び代謝性アシドーシスを引き起こす疾患 (糖尿病, 腎不全, 下痢, 乳酸性アシドーシス, 尿細管性アシドーシス等) $)^{4)}$ のほかに中耳圧左右 差は血液ガス異常と共にめまいのリスクを高める ことが示唆される。

檜 ${ }^{47)}$ 48) や山田 ${ }^{49)}$ は頸部, 腰部深部受容器や脊 柱側弯症によるめまいを報告し, Morinaka ${ }^{50)}$ は 筋骨格疾患全般について頸性めまいとの関連につ いて検討して報告した。側弯症では胸郭の変形に より肺のスペースが狭くなり呼吸器症状が出現す ることや慢性呼吸性アシドーシスが起こることが 知られており，また胸椎の前弯でも肺機能障害が 起こることが知られている ${ }^{5152)}$ 。筋骨格疾患とめ まいは深部受容器の問題以外にも血中 $\mathrm{O}_{2}, \mathrm{CO}_{2}$, 酸塩基平衡異常と関連することもありえるのでは ないかと考えられ今後の検討課題の 1 つと思われ る。

\section{おわりに}

酸塩基平衡異常とめまいの関連について過去の 文献を引用し，私見を交えて報告した。めまい疾 患では生体内の変化や生体外の環境変化が複雑に 関与することも検討されるべきと考える。

\section{文 献}

1) 福井俊夫 : 酸塩基平衡異常. A. 酸塩基平衡 とは. 山林一, 河合 忠, 塚本玲三 編. 血液ガス一わかりやすい基礎知識と臨床応 用一. 78-79頁, 医学書院, 東京, 1982

2) Driscoll P, Brown T, Gwinnutt C, et al.: A simple guide to blood gas analysis. 片山正 夫 監訳. シンプルガイド 血液ガス. 3441頁, 医学書院, 東京, 2009

3）太田保世：血液ガスとは．A. 血液ガスと酸 塩基平衡. 山林一, 河合 忠, 塚本玲三編. 血液ガス 一わかりやすい基礎知識と臨床応 
用一. 2-4 頁, 医学書院，東京， 1982

4) 太田保世：血液ガスと臨床応用. B 3. 血液 ガス異常の病型. 山林一, 河合 忠, 塚本 玲三 編. 血液ガス一わかりやすい基礎知識 と臨床応用一. 37-38頁, 医学書院, 東京, 1982

5 ) 近藤楠吉：炭酸瓦斯中毒ノ前庭性眼球運動二 及ボス影響二就テ.耳鼻臨床 $23: 126-$ 135, 1929

6 ) Morinaka S: Effect of experimental acidosis on nystagmus in rabbits. Acta Otolaryngol 114: 130-134, 1994

7 ) Tsujikawa S, Yamashita T, Tomoda K, et al.: Effects of acetazolamide on acid-base balance in the endolymphatic sac of the guinea pig. Acta Otolaryngol Suppl 500: 50-53, 1993

8 ) Couloigner V, Teixeira M, Hulin P, et al.: Effect of locally applied drugs on the $\mathrm{pH}$ of luminal fluid in the endolymphatic sac of guinea pig. Am J Physiol Regul Integr Comp Physiol 279: R 1695-R 1700, 2000

9 ) Stanković KM, Brown D, Alper SL, et al.: Localization of $\mathrm{pH}$ regulating proteins $\mathrm{H}^{+} \mathrm{AT}$ Pase and $\mathrm{Cl}^{-} / \mathrm{HCO}_{3}{ }^{-}$exchanger in the guinea pig inner ear. Hear Res 114:2134,1997

10) Dou H, Xu J, Wang Z, et al.: Co-expression of pendrin, vacuolar $\mathrm{H}^{+}$-ATPase alpha 4-subunit and carbonic anhydrase II in epithelial cells of the murine endolymphatic sac. J Histochem Cytochem 52: 1377-1384, 2004

11）福井俊夫 : 酸塩基平衡異常. B. 酸塩基平衡 の基礎的事項. 山林一, 河合 忠, 塚本玲 三 編. 血液ガス一わかりやすい基礎知識と 臨床応用一. 79-84頁, 医学書院, 東京, 1982

12) Supuran CT: Carbonic anhydrases as drug targets - an overview. Curr Top Med Chem 7: 825-833, 2007

13) Li X, Alvarez B, Casey JR, et al.: Carbonic anhydrase II binds to and enhances activity of the $\mathrm{Na}^{+} / \mathrm{H}^{+}$exchanger. J Biol Chem 277: 36085-36091, 2002

14) Yamashita H, Bagger-Sjöbâck D, Sekitani T: Expression of carbonic anhydrase isoenzymes in the developing endolymphatic sac of the human fetus and the mouse embryo. J Laryngol Otol 106: 98-102, 1992

15) Toei M, Saum R, Forgac M: Regulation and isoform function of the V-ATPase. Biochemistry 49: 4715-4723, 2010

16) Dossena S, Nofziger C, Tamma G, et al.: Molecular and functional characterization of human pendrin and its allelic variants. Cell Physiol Biochem 28: 451-466, 2011

17) Everett LA, Morsli H, Wu DK, et al.: Expression pattern of the mouse ortholog of the Pendred's syndrome gene $(P d s)$ suggests a key role for pendrin in the inner ear. Proc Natl Acad Sci USA 96: 9727-9732, 1999

18) Verkman AS: Aquaporins at a glance. J Cell Sci 124: 2107-2112, 2011

19) Fukushima M, Kitahara $T$, Uno $Y$, et al.: Effects of intra tympanic injection of steroids on changes in rat inner ear aquaporin expression. Acta Otolaryngol 122: 600-606, 2002

20) Taguchi D, Takeda T, Kakigi A, et al.: Expression and immunolocalization of aquaporin-6 (Aqp 6) in the rat inner ear. Acta Otolaryngol 128: 832-840, 2008

21) Royaux IE, Belyantseva IA, Wu T, et al.: Localization and functional studies of pendrin in the mouse inner ear provide insight about the etiology of deafness in Pendred syndrome. J Assoc Res Otolaryngol 4: 394-404, 2003

22) Azroyan A, Laghmani K,Crambert G, et al.: Regulation of pendren by $\mathrm{pH}$ : dependence on glycosylation. Biochem J 434: 61-72, 2011

23) Sterkers O, Saumon G, Tran Ba Huy P, et al.: Electrochemical heterogeneity of the cochlear endolymph: effect of acetazolamide. Am J Physiol 246: F 47-53, 1984

24) Mori N, Ninoyu O, Morgenstern C: Cation transport in the ampulla of the semicircular canal and in the endolymphatic sac. Arch Otorhinolaryngol 244: 61-65, 1987

25) Stankoviić KM, Adams JC, Brown D: Immunolocalization of aquaporin CHIP in the guinea pig inner ear. Am J Physiol 269: C 
1450-1456, 1995

26) Mori N, Uozumi N, Furuta $H$, et al.: Effect of acetazolamide on cation concentration in the endolymph of the endolymphatic sac. Acta Otolaryngol Suppl 533: 12-15, 1998

27) Couloigner V, Teixeira M, Bozorg-Grayeli A, et al.: $\mathrm{H}^{+}$. $\mathrm{K}^{+}$-ATPase is not involved in endolymph $\mathrm{pH}$ homeostasis. Acta Otolaryngol 121: 122-124, 2001

28）高橋三郎, 棚橋聡子, 旧井和子：メニエル病 例のメマイ発作時の血液ガス所見. 日耳鼻会 報 84：206-207, 1981

29）高橋三郎, 野田三洋子, 伊藤敬子, 他 : メ二 エル病症例の眩㟦発作に伴う代謝と平衡機能 の観察。岐阜市民病年報 $2 ：$ 49-60, 1982

30）牧本一男：メニエール病薬物療法における血 清電解質測定並びに血液ガス分析. 切替一 郎, 後藤修二 編. 耳鼻咽喉科診療二頁の秘 訣. 156-157頁, 金原出版, 東京, 1977

31) Celestino D, Iannetti G: Meniere's disease and plasmatic hyperosmolarity. J Laryngol Otol 87: 229-234, 1973

32) Celestino D, Cerulli N, Iannetti G, et al.: Acid -base equilibrium in Meniere's disease. J Laryngol Otol 90: 263-275, 1976

33) Morinaka S, Nakamura H: Arterial blood gas abnormalities in patients with dizziness. Ann Otol Rhinol Laryngol 107: 6-9, 1998

34) Paparella MM, da Costa SS, Fox R, et al.: Meniere's disease and other labyrinthine diseases. In eds Paparella MM, Shumrick DA, Gluckman JL, et al. Otolaryngology, 3 rd ed. pp 1689-1696, W. B. Saunders Company, Philadelphia, 1991

35）日本平衡神経科学会 めまいの診断基準化委 員会 委員長 小松崎篤, 委員 二木 隆, 原田康夫, 朴沢二郎, 他 : めまいの診断基準 化のための資料一1987年めまいの診断基準化 委員会答申書一. Equilibrium Res Suppl 11: 29-57, 1995

36) Morinaka S, Nakamura H: Middle ear pressure in patients with dizziness. Ann Otol Rhinol Laryngol 113: 906-913, 2004

37) Tumarkin A: Thoughts on the treatment of labyrinthopathy. J Laryngol Otol 80: 10411053, 1966

38) Hall MC, Brackmann DE: Eustachian tube blockage and Meniere's disease. Arch Otolaryngol 103: 355-357, 1977

39) Merica FW: Vertigo due to obstruction of the Eustachian tubes - a clinical study based on one hundred and thirty-five cases. JAMA 118: 1282-1284, 1942

40) Cinnamond MJ: Eustachian tube function in Meniere's disease. J Laryngol Otol 89: 5761,1975

41) Maier W, Ross U, Fradis M, et al.: Middle ear pressure and dysfunction of the labyrinth: is there a relationship? Ann Otol Rhinol Laryngol 106: 478-482,1997

42) Sakikawa Y, Wall CIII, Kimura RS: Vestibular responses of normal and hydropic ears of the guinea pig to middle ear pressure application. Ann Otol Rhinol Laryngol 108: 271-276, 1999

43) Ingelstedt $S$, Ivarsson A, Tjernstrom Ö: Vertigo due to relative overpressure in the middle ear. An experimental study in man. Acta Otolaryngol 78: 1-14, 1974

44) Park JJ, Luecke K, Luedeke I, et al.: Longterm middle ear pressure measurements in inner ear disorders. Acta Otolaryngol 132: 266-270, 2012

45) Buckingham RA, Stuart DR, Geick MR, et al.: Experimental evidence against middle ear oxygen absorption. Laryngoscope 95: 437442, 1985

46) Sade J, Luntz M: Gas diffusion in the middle ear. Acta Otolaryngol 111: 354-357, 1999

47) Hinoki M: Scoliosis and body equilibrium A neurotogical approach-. In Vertigo viewed from neurotology. pp 284-304, Kanehara \& Co., Ltd., Tokyo, 2003

48）檜學：めまいを考える一過去・現在・未 来一. 檜學監修. 牛尾信也, 近藤正彦, 岡田 修治，他編．金原出版，東京，1997

49）山田憲吾 : 脊柱側弯症と平衡機能. 耳鼻臨床 69 増 3 : 1224-1235, 1976

50) Morinaka S: Musculoskeletal diseases as a 
causal factor of cervical vertigo. Auris Nasus Larynx 36: 649-654, 2009

51）日本側弯症学会編：知っておきたい脊柱側弯 症. 26頁, インテルナ出版, 東京, 2010
52) Driscoll P, Brown T, Gwinnutt C, et al.: A simple guide to blood gas analysis. 片山正 夫 監訳. シンプルガイド 血液ガス. 5881頁, 医学書院, 東京, 2009 